\title{
HISTORICAL INTRODUCTION: THE EXPERIENCE AND MEMORY OF TRENCHES NEAR THE SOČA RIVER
}

\author{
Marko Štepec \\ MA, historian, museum councilor \\ National Museum of Contemporary History, Slovenia \\ e-mail:marko.stepec@guest.arnes.si
}

\begin{abstract}
The First World War brought many changes to everyday life and came as a surprise to many contemporaries. The territory of today's Slovenia mostly belonged to the 3rd Austro-Hungarian Army Corps. More than 160,000 soldiers were mobilized in these recruiting districts. The fact that the labor of at least five people was needed to provide for just one soldier on the frontline sums up how the hinterland was connected with the front. The fatalities among the soldiers were extremely high. During the first five offensives, the positions of the front were basically unchanged despite a large number of casualties. The Italian conquest of Gorica/Gorizia in August 1916 was followed by a new wave of refugees and the retreat of the Austro-Hungarian Army from the Doberdob/ Doberdo Plateau to the new defense line in the Karst region. The atmosphere in the hinterland was affected by a feeling of scarcity and growing discontent. With the successful breakthrough in 1917 (the battle of Caporetto), which shifted the front to the Piave River, the Isonzo Front drew the attention of military strategists and became known internationally. At the end of October 1918, Austria-Hungary collapsed and new states emerged on its territory, among them the State of the Slovenes, Croats, and Serbs. Thus the stories of the soldiers and the memory of the fallen remained within the family circle and local cemeteries, far from national celebrations, out of the collective memory of the new state. Later, the memory of the Second World War and the postwar revolution also completely obscured the memory of the years 1914-1918. A characteristic feature of Slovenia in the period after the Second World War was that the first museum collections were created by private collectors, who collected material remains of the war on the trackless Soča landscape.
\end{abstract}

Keywords: Austro-Hungarian Army, First World War, Isonzo Front, Italian Army, offensive, Soča River, soldiers

The First World War brought many changes to everyday life and came as a surprise to many contemporaries. The war as the pinnacle and breakdown of modernization processes actually changed or destroyed the spiritual and social 
basis of the old world. Its "absurdity was the dust that covered European civilization and placed its 'culture' under a huge question mark" (Kranjc 2001: 18).

The territory of today's Slovenia mostly belonged to the 3rd Austro-Hungarian Army Corps. The population of this area contained only 2 percent of the fifty-two million inhabitants of the country. More than 160,000 soldiers were mobilized in these recruiting districts. Until the end of May 1915, they fought on the Eastern Front against the Russian Army, and many fewer of them on the Balkan Front against Serbia. At the same time, in the distant hinterland of Slovenian regions, a militarization of the economy and a food crisis took place. The well-organized war propaganda skillfully exploited and encouraged patriotic feelings and spread stereotypes about the enemies. Careful management in collecting metal and other raw materials took place, and mottos such as "Gold for Iron", "Grain Days", "Handkerchief Days", and other patriotic charitable collection drives were part of everyday life.

After Italy had joined the war on the side of the Entente, fierce fighting between the Italian and Austro-Hungarian armies took place along the Soča River (Italian: Isonzo) from the end of May 1915 to the end of October 1917. By attacking Austria-Hungary, the Kingdom of Italy fulfilled its obligation under the Treaty of London, concluded between Italy and the Entente Powers in April 1915. The secret part of the treaty promised significant parts of AustroHungarian territory to Italy. The Italian strategic military plan envisaged a breakthrough towards Austria-Hungary toward the Soča River, across the Karst Plateau to the interior of the monarchy, whereby it would deal it a mortal blow and take it out of the war. The Isonzo Front saw eleven Italian offensives and one joint Austro-Hungarian-German offensive. Both sides removed the civilian population from the area of the fighting to various refugee camps.

Heavily loaded carriages creaked, the cattle mooed, and children sobbed while the adults wiped their bloodshot eyes and desperately looked back to the homes they had lost. We exchanged bitter and sympathetic looks and wished each other a safe journey. (Matičič 1922: 31)

After the fighting started along the Soča River, a wide territory behind the frontline belonged to the narrow zone of the military hinterland, in which special martial law was enforced. Behind the frontline there was a well-structured system of hospitals, prison camps, and military workshops. The fact that the labor of at least five people was needed to provide for just one soldier on the frontline sums up how the hinterland was connected with the front, where every day trains, carts, and cableways delivered hundreds of tons of military equipment, ammunition, arms, and replacement battalions of soldiers from all the nations of the monarchy. 


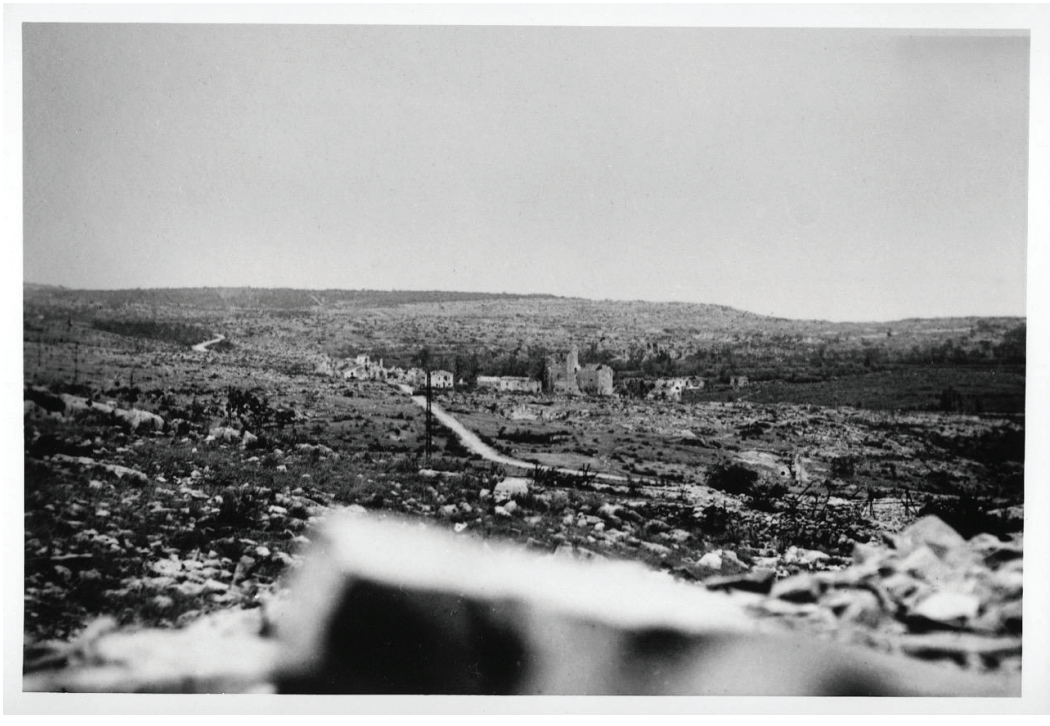

Figure 1. A view of the traces of battles on the Karst battlefield. Courtesy of the National Museum of Contemporary History, Slovenia.

Summing up the experiences of the soldiers that had spent twenty-nine months lingering on and dying on both sides of the frontline, it can be concluded that the living conditions were extremely poor. The soldiers were exhausted, dirty, and ragged, and they suffered from lack of sleep. Unburied corpses remained lying on the battlefield, and rats and lice multiplied (Štepec 2016: 32). Infectious diseases, including cholera and typhoid, spread in the trenches. The defense positions at the beginning were only temporarily fortified and hastily built, and so they offered poor protection from the fierce artillery bombardments. Scant supplies of water and thirst were a huge problem due to the stony Karst terrain with intense sunshine.

Although it was strictly forbidden to use the liquid, which was more like black coffee than water, it did not help. They did not just drink this poison themselves; they also filled their canteens with it and brought it to their comrades. Hunger is bad, but thirst is much worse. Today it disgusts us to think of what we drank then. (Pepernik 2005: 79)

In the northern sector of the battlefield, soldiers faced extremely difficult weather conditions and problems with regular supplies. The offensive operations of the Isonzo Front often started with artillery preparations lasting a few hours or days, and were followed by infantry attacks across no-man's land traversed 
by barbed wire. The defenders tried to stop the attackers with fierce artillery shelling, heavy rifle fire, mortars, and flame-thrower fire. If the attackers succeeded in reaching the enemy's positions, they faced completely insane shellshocked soldiers with their rifles, bayonets, and sharpened shovels. Despite the modern military technology, a hidden barbaric essence of war surfaced at that particular time. "We were no longer people, not even wild beasts, but simply something else without a name. All human feelings were frozen in us; we had lost everything that we had," wrote private Jakob Zemljič (Rihtarič 1999: 16). The fatalities among the soldiers were extremely high, and those that survived were eager to be replaced and removed from the first frontline. Many of them were wounded or suffered from mental illness as a consequence of such a shock. The poet Avgust Fabjančič recalled:

The air pressure threw me aside, but a piece of the shell tore the pocket on my left side, in which I had my notebook of poems. When I came to, I saw that the shell had torn my comrade to pieces, who was from somewhere near Braslovče ... I gathered up the shredded poems, my notebook. Those three days and nights of terror cannot be described, such can only be experienced. And you had to have strong nerves not to go mad. (Štepec 2014a: 53)

Those that survived the battles were disinfected and sent on leave to military places of amusement, hospitals, or to the hinterland only to later return to the battlefields. These procedures took place during all the eleven offensives that are now known as the Isonzo Front. During the first five offensives, the positions of the front were basically unchanged despite the large number of casualties.

Towards morning, the enemy launched an attack on Hill V. By surprise, they succeeded in taking an important fortified position held by soldiers of the 42nd Infantry Regiment. Then a deathly silence occurred. As stretcher bearers, I [Giuseppe Cordano] and Rocchi tried to carry two seriously wounded Bersaglieri and one dead soldier to the first aid station. With that melancholy task, on top of the effort and danger, we thus also have real insight into the pain and tragedy we have fallen into. (Cimprič 2014: 44)

The Italian conquest of Mount Sabotin, which was a crucial defense position, was an important turning point of the Isonzo Front (Macdonald \& Cimprič 2011: 91). The Austro-Hungarian commanders were forced to order a retreat by the army and the evacuation of the rest of the civilians from Gorizia to the left bank of the Soča River. The Italian conquest of Gorizia was followed by a new wave of refugees and the retreat of the Austro-Hungarian Army from the Doberdò Plateau to the new defense line in the Karst region. 
Due to the growing military needs, a lack of labor and a food crisis soon arose and increased to the level of starvation throughout the country. The atmosphere in the hinterland was affected by a feeling of scarcity and growing discontent. In 1917, political demands to reform the monarchy stated in the Vienna parliament and expectations for peace increased in the rear. This new hope for an expected peace was interrupted by the noise of artillery fire in the area between Tolmin and the Adriatic Sea. The new and largest Italian offensive along the Soča River began on August 18, 1917 (Sedmak 2010: 32). Although the Italian Army once again failed to realize its aim, the Austro-Hungarian Army had to draw back its reserve defensive lines on the Banjšice Plateau. More than thirty thousand missing Austro-Hungarian soldiers (along with forty thousand Italian soldiers and ten thousand Austro-Hungarian soldiers dead) and a shortage of reserve units was more than a clear warning to the high command of the Austro-Hungarian Army that they would no longer be able to endure a similar offensive and that something needed to be done.

Thus the arrangements with the German allies started even before the Italian offensive had finished, and they decided that a joint offensive called Waffentreue (Loyalty in Arms) would begin in the Upper Soča Valley. For the needs of the offensive, they had to transport the necessary military equipment, artillery, ammunition, and troops to the Upper Soča Valley, which had a poor communication system. One hundred and twenty military transports passed the Ljubljana railway station every day in October. It is no wonder that the Ljubljana lawyer Fran Milčinski wrote in his diary: "Our own planes above Ljubljana every day, troops and transports along the roads - large wagons pulled by three pairs of horses. A high, dense constant dust lies like fog above the whole of Ljubljana" (Milčinski 2000: 288).

A joint army was formed. It consisted of six German divisions, mostly infantry, and five Austro-Hungarian divisions. They began the attack on October 24, 1917, at 2:05 am, when the order was given to begin with artillery and grenade attacks in a carefully planned sequence (Simić 1996: 195). The attack was especially intense in the area between Mount Rombon and Tolmin. Many grenades were marked with green, blue, and yellow crosses because they were filled with different gases. They had an enormous psychological effect. The efficient and short artillery preparations turned into an offensive attack at 9 am in Bovec. Franc Arnejc, a soldier in the 7th Infantry Regiment, was very emotional and horrified, and he wrote about the first day of the offensive:

This mournful thunder echoes and rebounds terribly from the mountain cliffs. You can't hear your voice, because of the very long persistent cracking. Most of these shells are filled with gas. Death now has a terrible 
harvest here. Our numerous cannons only heap up the human slaughter, there on the Italian side. The whole front is one big flame because of the bursting shells and shrapnel... The Italian battle line is a sad sight: full of dead and wounded lying all around here; the caves in many places are full of corpses because they crammed into them and perished there from poison gas. (Arnejc 1970: 79)

The German 12th division was successfully advancing in the area between Tolmin and Kobarid as well. On the first day of the offensive, the Italian defense line had already been broken through and a great number of Italian soldiers had been captured.

Artilleryman Albin Mlakar wrote in his diary about the first day of the breakthrough:

We froze by the cannons and waited for the weather to improve, but hopelessly... At night, our soldiers fired gas grenades. Some of the shots fell into our trenches and poisoned some soldiers, and they ripped off the arms and legs of a lieutenant, who later died. (Mlakar 1995: 164)

After the successful breakthrough between Tolmin and Kobarid, the frontline moved deep into the interior of Italy across the Piave River. After twenty-nine months of fighting, the weapons fell silent. With the successful breakthrough that shifted the front to the Piave River, the Isonzo Front drew the attention of military strategists and became known internationally. The frontline near the Piave River did not change again until the end of the monarchy. An unsuccessful June offensive merely increased the discontent, and at the end of October 1918 Austria-Hungary collapsed and new states emerged on its territory, among them the State of the Slovenes, Croats and Serbs. At the beginning of November, Austria-Hungary signed an armistice, and the Italian Army marched across the prewar Austro-Hungarian border with Italy.

After the war, families, war veterans, and the church in cooperation with local communities began to erect memorial plaques and monuments to the fallen soldiers. However, they only rarely listened to survivors when they talked about their often traumatic wartime experiences. It seems that everyone just wanted to forget the war as soon as possible. Thus the stories of the soldiers and the memory of the fallen remained within the family circle and local cemeteries, far from national celebrations, out of the collective memory of the new state (Štepec 2014b: 64). In the everyday propaganda of the new state, Austria-Hungary became a more or less hated "prison of nations". Its army, which had lost the war, was considered alien, "not ours", and it was written out of school books. It must be remembered that the soldiers of various nations that made up the new 


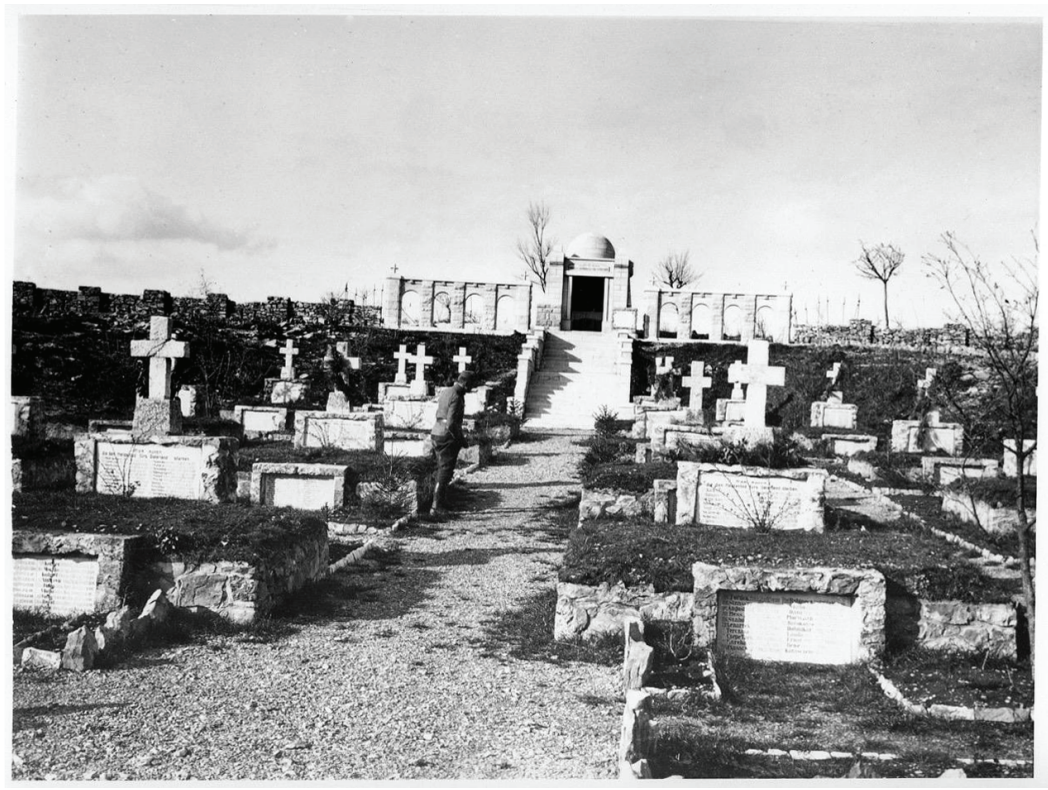

Figure 2. Austro-Hungarian military cemetery at Gorjansko. Courtesy of the National Museum of Contemporary History, Slovenia.

state had fought on opposing sides, which had a significant impact on the formation of a common state memory. Even the Isonzo Front, which ran through the Slovenian territory near the Soča River, and units from Slovenian mobilization regions, who fought and died on battlefields from the Karst Plateau to Mount Rombon, did not receive the expected space in school curricula (Svoljšak 1993: 276). Later, the memory of the Second World War and the postwar revolution also completely obscured the memory of the years 1914-1918.

A characteristic feature of Slovenia in the period after the Second World War was that the first museum collections were created by private collectors, who gathered material remains of the war on the trackless Soča landscape. The war was deeply imprinted in the landscape and its traces could be found in the changed appearance of the environment, crisscrossed with kilometers of trenches, military constructions, roads, barbed wire, material remains, weapons, shells, and military equipment. There are also many military cemeteries and monuments from the Adriatic Sea to Mount Rombon that are reminders of the huge numbers of fallen soldiers. The attitude towards the Great War and Isonzo Front heritage in these hundred years has turned from marginalization and oblivion to an important part of collective memory in Slovenia. 


\section{ACKNOWLEDGEMENTS}

This article was written within the framework of the special issue titled Cultural Heritage of the Great War (Traditiones, Vol. 47, No. 1, 2018, edited by Božidar Jezernik and \& Jurij Fikfak).

\section{REFERENCES}

Arnejc, Franc 1970. Od Dnestra do Piave: Spomini iz prve svetovne vojne. [From the Dnester to the Piave River: Memories from First World War.] Klagenfurt: Družba Sv. Mohorja.

Cimprič, Željko 2014. Giuseppe Cordano. In: Štepec, Marko (ed.) We Never Imagined Such a War. Ljubljana: National Museum of Contemporary History, pp. 43-44.

Kranjc, Igor 2001. France Kralj. Ljubljana: Slovenska matica.

Macdonald, John \& Cimprič, Željko 2011. Caporetto and the Isonzo Campaign: The Italian Front 1915-1918. Barnsley, UK: Pen \& Sword Books.

Matičič, Ivan 1922. Na krvavih poljanah. Trpljenje in strahote z bojnih pohodov bivšega slovenskega planinskega polka. [On the Blood-Soaked Plains: Suffering and Horrors of the Battle Marches of the Former Slovene Mountain Regiment.] Ljubljana: Učiteljska tiskarna.

Milčinski, Fran 2000. Dneunik 1914-1920. [Diary 1914-1920.] Ljubljana: Slovenska matica.

Mlakar, Albin 1995. Dneunik 1914-1918. [Diary 1914-1918.] Kobarid: Turistična agencija K.C.K.

Pepernik, Amandus 2005. Doberdob, slovenskih fantov grob. [Doberdob, the Grave of Slovenian Soldiers.] Ljubljana: Karantanija.

Rihtarič, Ivan (ed.) 1999. Jakob Zemljič: Spomini iz svetovne vojske. [Jakob Zemljič: World War II Memories.] Glasilo letnik, Vol. 6, No. 1, pp. 11-18.

Sedmak, Drago 2010. Isonzo (Soča) Front. In: Slovenci in prva svetovna vojna 1914-1918. [Slovenians and the First World War 1914-1918.] Ljubljana: National Museum of Contemporary History, pp. 47-49.

Simić, Marko 1996. Po sledeh soške fronte. [Following the Traces of the Isonzo/Soča Front.] Ljubljana: Mladinska knjiga.

Štepec, Marko 2014a. Avgust Fabjančič. In: Štepec, Marko (ed.) We Never Imagined Such a War. Ljubljana: National Museum of Contemporary History, p. 53.

Štepec, Marko 2014b. Memory. In: Štepec, Marko (ed.) We Never Imagined Such a War. Ljubljana: National Museum of Contemporary History, p. 64.

Štepec, Marko 2016. "Bedna kritja pod planoto tik nad Sočo": v strelskih jarkih soškega bojišča 1915-1917. ["Miserable Covers under the Plateau above the Isonzo": In the Trenches of the Isonzo/Soča Front 1915-1917.] Zgodovina $v$ šoli, Vol. 24, No. 1-2, pp. 29-38. Available at http://sistory.si/11686/38264, last accessed on 13 September 2018.

Svoljšak, Petra 1993. Prva svetovna vojna in Slovenci. [The First World War and the Slovenes.] Zgodovinski časopis, Vol. 47, No. 2, pp. 263-288. Available at http:// www.zgodovinskicasopis.si/_pdf/Digital-archive/ZC_1993_2.pdf, last accessed on 13 September 2018. 